\title{
The thermal stress response to diel vertical migration in the hyperiid amphipod Phronima sedentaria
}

\author{
Leanne E. Elder ${ }^{\text {a, }}{ }^{*}, 1$, Brad A. Seibel ${ }^{\text {a }}$ \\ ${ }^{a}$ Biological Sciences Department, University of Rhode Island, 120 Flagg Road, Kingston, RI 02881, USA \\ ${ }^{1}$ Present address: Department of Geology and Geophysics, Yale University, PO Box 208109, New Haven, CT, \\ 06520-8109 USA
}

Running title: Thermal Stress response in Phronima sedentaria

ms. has 29 Pages, 6 figures, 1 table

* Corresponding author:

Dr. Leanne Elder

Department of Geology and Geophysics, Yale University, PO Box 208109,

New Haven, CT 06520-8109 USA

Tel: +18608052211

Leanne.elder@yale.edu,

\begin{abstract}
The hyperiid amphipod Phronima sedentaria experiences a temperature change of $15^{\circ} \mathrm{C}$ during diel migration in the Eastern Tropical North Pacific (ETNP) from $8-10^{\circ} \mathrm{C}$ at depth to $25-27^{\circ} \mathrm{C}$ at night in the surface waters. The aim of this study was to determine if the natural temperature gradient experienced by Phronima sedentaria results in a thermal stress response. Individuals were initially exposed to their night time temperatures $\left(23^{\circ} \mathrm{C}\right)$ and subsequently subjected to temperatures within and above the range they typically experience. In the Eastern Tropical North Pacific $P$. sedentaria tolerates its normal night-time temperature $\left(\sim 23^{\circ} \mathrm{C}\right)$, but only for the duration of its stay there ( $\sim 9$ hours). Longer exposures ( 24 hours) result in elevated heat shock
\end{abstract}


protein (hsp) expression. $29^{\circ} \mathrm{C}$ results in hsp expression, increased lactate production and 50\% mortality at all exposure durations. This represents an upper critical temperature. Understanding the adaptations of pelagic amphipods to their current environment will help predict the physiological impacts of global warming for amphipods and their predators.

Keywords: Phronima, hsp70, thermal stress, hyperiid amphipod, diel vertical migration, critical temperature, oxygen limited thermal tolerance

\section{Introduction}

Environmental changes that cause a reduction in performance or fitness are known as stress factors (sometimes referred to as stressors) (Schulte, 2014). Abiotic stress factors include hypoxia, acidification, and thermal extremes to name a few. Stress factors vary in temporal scale and level of intensity; from gradual seasonal changes, to drastic tidal or migratory variation. When one of these stress factors is impacting biological function of an organism (fitness) it is referred to as stressful or a stress (Schulte, 2014; Sørensen et al., 2003). The stress response of an organism is the behavioral and physiological adjustments to attempt to maintain fitness (Schulte, 2014). During thermal stress enzymatic and structural proteins denature (unfold) which impacts their stability and kinetic properties (Somero, 1995). The stress response to thermal stress includes expressing heat shock proteins (hsps) (DuBeau et al., 1998) as well as antioxidases, proteases and DNA repairs systems (Sørensen et al., 2003). Hsps act as molecular chaperones that are able to prevent/reduce denaturing of proteins and target those that are irreversibly denatured for removal from the cell via the ubiquitin-proteosome pathway. Hsp 70 is one of the 
most highly conserved heat shock proteins expressed in response to hypoxia and osmotic stress and is especially noted for its role in recovery from thermal stress (Feder and Hofmann, 1999). During stress the amount of denatured proteins increases, which requires hsp 70 to chaperone these proteins to prevent damage to the cell. In response to thermal stress there is an upregulation of hsp 70 concentrations proportional to the amount of denatured proteins. Therefore Hsp 70 is a biochemical indicator for the degree of protein unfolding in a cell and an indirect gauge of protein damage (Hofmann, 2005). At a certain upper temperature beyond optimal conditions, referred to as the critical temperature, organisms are not able to perform normally. At this critical temperature there is an increase in hsp expression and a failure of ventilatory or circulatory systems which results in reduced aerobic scope. This reduction in aerobic scope occurs even in oxygenated conditions and results in the transition to anaerobic metabolism in an attempt to continue ATP production (Pörtner, 2010).

The thermal stress response is especially important for aquatic ectotherms since their body temperature fluctuates over the full range of their habitat temperatures (Sokolova and Portner, 2003). Diel migrators experience large temperature changes in their natural environment, spending the day in deeper colder waters and nighttime foraging near the surface. Phronima sedentaria (Forskål, 1775) is an abundant species of diel migrating hyperiid amphipod found throughout the world oceans (Shih, 1969; Shulenberger, 1977; Vinogradov et al., 1996; Voznesensky et al., 2004). P. sedentaria exhibits no apparent differences among age classes in its patterns of diel migration (Diebel, 1988).

While most pelagic species of amphipods "hitch-hike" on gelatinous zooplankton that serve as physical and metabolic substrate (Gasca and Haddock, 2004; Harbison et al., 1977; Madin and Harbison, 1977), the relationship between $P$. sedentaria and its parasitized host is unique in that 
the host is transformed by the parasite (Land, 1992). Phronimids eat the internal tissue of their siphonphore or tunicate host leaving the remaining gelatinous matrix in a barrel shape brood chamber (Diebel, 1988; Hirose et al., 2005; Laval, 1978) that is propelled through the water with the urosoma (tail) (Land, 1992).

P. sedentaria may encounter a temperature change of $15^{\circ} \mathrm{C}$ during its diel vertical migrations, experiencing surface temperatures approaching $30^{\circ} \mathrm{C}$ in some regions. Such wide temperature variation within the natural range of a species can induce a stress response (Hofmann and Somero, 1995). Furthermore, the maximum habitat temperatures of many warm-adapted organisms (such as those found in the tropics) are near their upper critical temperature. Additional increases in temperature due to climate change may not be tolerated by such organisms (Somero, 2010). Oceanic temperatures have increased over the past century as a likely result of anthropogenic carbon dioxide emissions (Trenberth et al., 2007). Increasing environmental temperatures are predicted to affect the physiological performance, and consequently the vertical distribution and ecology of marine organisms (Doney et al., 2012; Saltzman and Wishner, 1997; Seibel, 2011; Somero, 2002). If existing night time temperatures are stressful for diel migrators and they are not able to adapt, their depth range will not be sustainable at current latitudes in the future. Determining how close to thermal limits zooplankton are currently living is an important step to project ecosystem response to climate change.

We determined the critical temperature for a tropical population of Phronima sedentaria from the Eastern Tropical North Pacific. The expression of hsp 70 and the production of the anaerobic end product, lactate, were quantified at temperatures spanning the range experienced by Phronima sedentaria across their vertical distribution to determine what temperatures induce a 
stress response. Individuals were exposed to these temperatures for durations equivalent to the approximate time they are at the surface (9 hours) as well as shorter and longer time frames. We tested the hypothesis that the highest temperatures experienced within the natural range can induce a stress response that would result in an increase in synthesis in heat shock protein 70, and a shift to anaerobic metabolism.

\section{Materials and methods}

\subsection{Collection}

Phronima sedentaria (Figure 1) were collected in the Eastern Tropical North Pacific (ETNP) at the Costa Rica Dome $\left(8.5^{\circ} \mathrm{N} ; 90^{\circ} \mathrm{W}\right.$; Figure 1$)$. The research cruise on the R/V Knorr (Woods Hole Oceanographic Institute) was from 8 December 2008 - 6 January 2009. Collection was done using a tucker trawl with a thermally insulated cod end (Childress et al., 1978). Individuals were identified according to published taxonomic keys (Shih, 1991; Vinogradov et al., 1996). Physical vouchers to confirm the identification were preserved in formaldehyde and housed in the Seibel lab at the University of Rhode Island.

Individuals were collected from two separate trawls on January $1^{\text {st }}$ and $2^{\text {nd }} 2009$ in discrete tows between the depths of 250 and $300 \mathrm{~m}$ with a speed of $1.5-2$ knots. The first trawl was opened at depth at 1509 local time (2109 GMT) at $09^{\circ} 10.4370 \mathrm{~N}, 89^{\circ} 56.5019 \mathrm{~W}$ and closed at 1539 (2139 GMT). The second tow was opened at depth at 1525 local time (2125 GMT) at $09^{\circ}$ $01.6328 \mathrm{~N}, 89^{\circ} 59.1241 \mathrm{~W}$ and closed at 1614 local time (2214 GMT). The shipboard CTD was SBE9+ (Sea-Bird electronics, USA) and included sensors for oxygen (SBE 43), temperature (SBE 3T), conductivity (SBE 4C), pressure (Digiquartz) and a SBE 5 pump. CTD data from the 
same day show that the ambient temperature where these individuals were collected was approximately $12^{\circ}$ Celsius (Figure 2). Sightings from blue water SCUBA diving, and other trawls have shown that this species can be found near the surface at night in water at temperatures of $23-25^{\circ}$ Celsius (personal observations). Collection at depth provided control of the duration individuals were exposed to surface temperatures.

\subsection{Thermal stress}

We employed a unique experimental protocol designed to test both the time-relative tolerance to, and recovery from, the natural night-time temperatures experienced by Phronima sedentaria. Individuals were sorted immediately after retrieval and identified quickly under a microscope to reduce stress. Individuals in good condition (intact with no injuries) were separated into chilled filtered seawater until experimentation and held for a maximum of a half hour before initial treatments. For the initial exposure treatment (I-exposure) individuals were placed in plastic containers with 0.2 micron filtered sea water at their approximate nighttime temperature $\left(23^{\circ} \mathrm{C}\right)$ for 3, 9 or 24 hours. The 9 hour exposure is similar to the duration diel migrators spend in surface waters.

For the subsequent exposure (S-exposure) individuals were then transferred to open scintillation vials ( $25 \mathrm{ml}$ volume) containing 0.2 micron filtered seawater at $23^{\circ} \mathrm{C}$ and placed in separate wells of an aluminum thermal gradient block (Figure 3, (Henkel and Hofmann, 2008). The vials took $\sim 15$ minutes to get to the desired temperature. S-exposures lasted five hours at temperatures: 10, $15,20,23,25$ and $29 \pm 1{ }^{\circ} \mathrm{C}$.

The thermal block consisted of a piece of aluminum with holes drilled through each end fitted with brass inlet and outlet ports to accommodate heating and chilling lines. The heating and chilling lines were connected to temperature controlled water baths (Lauda, Germany). Water 
flowed directly against the aluminum for optimal thermal transfer. Evenly spaced wells were drilled in the top of the block in rows of four to allow up to four replicated experiments at each temperature. Prior to experiments the wells were filled with fresh water and allowed to come to temperature. Once the wells were at the appropriate temperature the scintillation vials with filtered seawater and the individual $P$. sedentaria were floated in the well.

Table 1 outlines the number of individuals for each treatment. During the experiment the thermal block was loosely covered by black plastic bags to block light. Oxygen concentrations of the water in experimental vials was checked using a Clark-type oxygen electrode (1302 Strathkelvin Instruments, United Kingdom; (Clark, 1956)) to make sure water remained well above the published critical oxygen partial pressure of $2.11 \mathrm{kPa}\left(28 \mu \mathrm{M}\right.$ at $10^{\circ} \mathrm{C}$ (Childress, 1975). For this study 24 hour I-exposure specimens were frozen at 0100, 9 hour I-exposure specimens were frozen at 1300 and 3 hour I-exposure specimens were frozen at 0700 . No significant differences were found between individuals run at different times of day and results are combined for all analyses. Following S-exposure, individuals were then taken out of the vial with feather forceps and blotted dry before being immersed in liquid nitrogen and stored at -80 degrees Celsius.

\subsection{Lactate}

Individual whole frozen individuals were ground on ice in a prechilled glass tissue homogenizer (Kimble Chase, USA) using a 1/3 dilution with grinding buffer, $465 \mathrm{~mm} \mathrm{NaCl}, 19 \mathrm{~mm} \mathrm{KCl,} 20$ mm Tris, 1mM EDTA, containing a 1 x protease inhibitor cocktail (Sigma p2714) and 0.1\% detergent (IGEPAL Sigma 18896). The homogenate was centrifuged at $2000 \mathrm{rpm}$ for five minutes at $4^{\circ} \mathrm{C}$ and the supernatant removed. L-lactate concentrations were measured on the Accutrend lactate meter using a $25 \mu \mathrm{l}$ sample of supernatant. All samples were assayed in 
duplicate and compared to a lactate standard curve (sodium lactate, L7022, Sigma- Aldrich, MO, USA) which was run daily. Remaining supernatant was flash frozen in liquid nitrogen and stored at -80 until needed for western blots.

\subsection{Western blots for hsp70 concentration}

Lysate was thawed on ice and centrifuged at $13400 \mathrm{rpm}$ for 2 minutes. Protein concentration was determined using the Pierce BCA protein assay (Bio-Rad, USA). Thirty $\mu \mathrm{g}$ total protein of each sample lysate was mixed with 1/3 lysate volume of 4x NuPAGE LDS buffer containing $10 \% \beta$ mercaptoethanol and then boiled for 10 minutes at $95^{\circ} \mathrm{C}$. Lysate was loaded on to $4-12 \%$ bis tris gels (Invitrogen). Heat shocked HeLa cells (Enzo, USA, ADI-LYC-HL101) were added as a control between gels by using their protein band for comparison of relative intensities between samples. Proteins were electrophoresed at $120 \mathrm{~V}$ for 15 minutes, and $150 \mathrm{~V}$ for approximately 2 hours in $1 X$ MOPS running buffer. Gels were soaked in transfer buffer (5.82g Tris, $2.93 \mathrm{~g}$ Glycine, 2x $940 \mu 120 \%$ SDS, 100mL Methanol, q.s. to 1000ml with deionized water) for 20 minutes and electroblotted (Bio Rad, Trans-blot 170-3940) for 30 minutes at 25 volts onto a polyvinylidene difluoride (PVDF) membranes (Fisher IPVH00010). The membrane was washed twice in 10X TBST (Tris Buffered Saline: $400 \mathrm{~g} \mathrm{NaCl}, 10 \mathrm{~g} \mathrm{KCl}, 150 \mathrm{~g}$ Tris, $5 \mathrm{~mL}$ tween into $4.5 \mathrm{~L}$ of DI water, $\mathrm{pH}$ of 7.4. quantum satis DI water for 5L total). The membrane was then blocked in $5 \%$ milk powder (diluted in TBST) for one hour at room temperature. This was followed by 3 five minute TBST washes. The membrane was then incubated in a 1:1,000 dilution of hsp 70 antiserum (Stressgen SPA-822) overnight at $4{ }^{\circ} \mathrm{C}$. After washing, the secondary antibody (antimouse Igc:HRP-Linked, GE Healthcare Biosciences NA931) was added for one hour at room temperature. 
Immunoreactive proteins were then visualized with Chemiluminecent substrate Western lightening (Perkin Elmer, NEL102001EA) for 2 minutes. Following a one minute exposure, on kodak biomax XAR film (Sigma, F5388-50EA) the film was developed and HSP 70 expression was determined semi-quantitatively using Image $\mathbf{J}$ software.

\subsection{Statistical analysis}

Statistics were performed using the software SAS version 9.3 (SAS institute inc. USA). One-way Analysis of Variance (ANOVA), with between subjects design were conducted to compare differences in lactate accumulation or hsp 70 concentration between treatments.

\section{Results}

\subsection{Collection}

At the time of collection surface temperatures of the ETNP were between 23 and $25^{\circ} \mathrm{C}$. The maximum surface temperature recorded in the ETNP during this cruise was $27^{\circ} \mathrm{C}$. Based on published distribution for Phronima sedentaria, temperatures at the deepest range of daily migrations are between 8 and $10^{\circ} \mathrm{C}$. This indicates Phronima sedentaria may experience a temperature change of $13-17^{\circ} \mathrm{C}$ in the ETNP during diel migration in the ETNP (Figure 2).

\subsection{Thermal stress, and Lactate concentrations}

There was no significant difference in mortality or lactate accumulation (ANOVA: $\mathrm{p}>0.1$ ) for 3, 9 or $24 \mathrm{~h} \mathrm{I-exposure} \mathrm{to} \mathrm{nighttime} \mathrm{temperature}\left(23^{\circ} \mathrm{C}\right)$. Data for those exposure times are averaged within each temperature for subsequent analyses of lactate concentrations. There was no 
significant difference in any parameter between experiments conducted at different times of the day. No further evaluation of diel rhythms was conducted.

There was no mortality of individuals between 10 and $20^{\circ} \mathrm{C}$. At $23^{\circ} \mathrm{C}, 1$ of 7 individuals died $(13 \%)$ and at $25^{\circ} \mathrm{C}, 2$ of 8 individuals died (30\%); Table 1). The most significant mortality occurred at $29^{\circ} \mathrm{C}$, at which temperature $50 \%$ of the experimental individuals died (4 out of 8 total individuals; Table 1). Dead individuals had a significantly higher accumulation of lactate, and so are not included further.

Exposure to $29^{\circ} \mathrm{C}$ resulted in a significant increase in lactate accumulation relative to all other temperatures (Figure 4; one way ANOVA, $\mathrm{F}(5,15)=8.26$; $\mathrm{p}=0.0025$ ). At $29^{\circ} \mathrm{C}$ the average Llactate production in live individuals was $20.5 \pm 4.52 \mu \mathrm{mol} \mathrm{g}^{-1}$. For all other S-exposure temperatures $\left(10-25^{\circ} \mathrm{C}\right)$ there was no significant difference in lactate accumulation. The average lactate accumulation after S-exposure to $10,15,20,23$ or $25^{\circ} \mathrm{C}$ was $2.89 \pm 0.797 \mu \mathrm{mol} \mathrm{g}{ }^{-1}$. A previous study on $P$. sedentaria found that individuals frozen immediately after collection had very high levels of lactate $\left(\geq 20 \mu \mathrm{mol} \mathrm{g}^{-1}\right)$ indicating use of anaerobic metabolism in oxygenated conditions, which is thought to be a result of capture stress (Elder and Seibel, In Revision). The low values measured here at temperatures below $29^{\circ} \mathrm{C}$ indicated that acclimation time was sufficient to recover from collection stress.

\subsection{Western blots}

Western blot analysis using an antibody for hsp 70 revealed one band occurring at approximately 70kDa (Figure 5). Due to low sample size, no significant differences were found between individuals S-exposed to 23 or $25^{\circ} \mathrm{C}$ following I-exposure at $23^{\circ} \mathrm{C}$. These individuals were combined and are designated $24^{\circ} \mathrm{C} \mathrm{S}$-exposure in Figure 6. Individuals I-exposed to $23^{\circ} \mathrm{C}$ for 
only 3 hours had significantly lower hsp70 levels than either 9 or 24 hour I-exposed individuals at all S- exposure temperatures (ANOVA: $\mathrm{F}(2,47)=7.82 ; \mathrm{p}<0.0012$; Figure 6). There was no difference in hsp70 expression between the 9 and $24 \mathrm{~h} \mathrm{I}$-exposures at 10-20 ${ }^{\circ} \mathrm{C} \mathrm{S}$-exposure. For individuals in the $24 \mathrm{~h} \mathrm{I}$-exposure, hsp70 levels were elevated at $29^{\circ} \mathrm{C}$ compared to lower temperatures for that I-exposure duration (Figure 6, ANOVA: $\mathrm{F}(5,24)=2.57, \mathrm{P}<0.0535$ ). Elevated temperature $\left(29^{\circ} \mathrm{C}\right)$ did not induce hsp70 expression in individuals I-exposed for 3 hours at $23^{\circ} \mathrm{C}$ (Figure 6). There were no significant differences in hsp expression within a single temperature for the S-exposures other than $29 \mathrm{C}$. At $10^{\circ} \mathrm{C}$ (one-way ANOVA $\mathrm{f}(2,8)=1.63$, $\mathrm{P}>0.2548$ ) and $15^{\circ} \mathrm{C}$ (one-way ANOVA $\left.\mathrm{f}(2,8)=1.85, \mathrm{p}>0.1675\right)$ there were nearly significant differences.

\section{Discussion}

During daily migrations Phronima sedentaria experiences a temperature change of $\sim 15^{\circ} \mathrm{C}$ (Figure 2) with sustained upper temperatures near $23^{\circ} \mathrm{C}$ at night. $P$. sedentaria migrates between the surface and 200-350m during diel migration (Shih, 1991; Shulenberger, 1977). This temperature change when migrating through the thermocline would be rapid, with a change of up $10^{\circ} \mathrm{C}$ degrees across 50m (Figure 2). For this study we assessed mortality, lactate and hsp 70 accumulations in individuals initially exposed to nighttime temperature $\left(23^{\circ} \mathrm{C}\right)$ for varying durations to assess both the time-sensitive stress response and required recovery temperature. The stress response consists of physiological adjustments to attempt to maintain fitness. We predicted that the temperatures routinely experienced by $P$. sedentaria within its natural range would induce a stress response. If this stress response occurred, it would result in a shift to anaerobic metabolism due to oxygen-limitation (discussed below; Pörtner, 2002) that can be 
measured as an increase in lactate production under oxygenated conditions. In addition, a stress response would result in an increase in hsp 70 concentrations. Three hour initial exposure individuals had consistently lower hsp 70 levels than individuals with 9 and 24 hour initial exposures (Figure 6). This indicates that longer durations did induce some stress response. There was an increase in both lactate and hsp 70 at $29^{\circ} \mathrm{C}$. Although this temperature was not experience during our expedition (January), surface temperatures in the Eastern North Tropical Pacific can reach $29^{\circ} \mathrm{C}$ (Pennington et al., 2006). It is possible that $P$. sedentaria adjusts their physiological temperature tolerance seasonally, a follow up study in this region in the summer would determine that. At the S-exposure temperatures other than $29^{\circ} \mathrm{C}$, there was no significant difference in hsp expression when comparing the I-exposure duration. This is in part because of large variation in hsp expression for the 9 and 24 hour individuals. At 10 and $15^{\circ} \mathrm{C}$ at least one individual at 9 and 24 hours had a low hsp expression similar to the 3 hour individuals. The $13 \%$ mortality at $23^{\circ} \mathrm{C}$ and $30 \%$ mortality at $25^{\circ} \mathrm{C}$ (Table 1 ) may indicate some amount of stress at night time temperatures (although sample sizes are too low to place much confidence in the mortality analysis). The modest heat-shock response observed may be necessary for these amphipods to survive the 8 hours typically spent in near-surface waters. In all initial exposure treatments, including 3-hour individuals, subsequent exposure to $24^{\circ} \mathrm{C}$ for five hours did not result in additional significant hsp70 expression. The less than $30 \%$ mortality and lack of an increase in lactate or hsp 70 suggests that $P$. sedentaria is tolerant of nighttime temperatures for at least 8 hours, equivalent to its nightly exposure duration before returning to cooler depths. Pörtner (2002) has suggested that upper critical temperatures are related to a mismatch between oxygen supply and demand. This is supported by an elevation in lactate at $29^{\circ} \mathrm{C}$. However, lactate levels did not increase at temperatures below $29^{\circ} \mathrm{C}$ at any initial exposure duration. This 
suggests that the heat-shock response in the 9 and 24-hour initial exposures is independent of oxygen stress. In addition temperatures below $23^{\circ} \mathrm{C}$ did not result in a reduced amount of lactate production or hsp70 concentrations (Figures 5 and 7), indicating that the low lactate levels measured were a true "basal" level. There was no significant mortality at temperatures below $23^{\circ} \mathrm{C}$ (Table 1). This suggests that the modest heat-shock response at temperatures below $29^{\circ} \mathrm{C}$ was successful at protecting the individual from detrimental effects of thermal stress. At $29^{\circ} \mathrm{C} \mathrm{P}$. sedentaria had a significant increase in lactate production (Figure 4), hsp 70 concentrations (Figure 6), and mortality (Table 1). This indicates that the critical temperature range for Phronima sedentaria in the ETNP is between 26 and $29^{\circ} \mathrm{C}$, which is slightly higher than the ambient surface temperatures during our winter expedition. Summer temperatures can surpass $29^{\circ} \mathrm{C}$ in the ETNP (Pennington et al., 2006).

The increase in lactate production at $29^{\circ} \mathrm{C}$ represents the onset of anaerobic metabolism. At their critical temperature, individuals may experience a failure of ventilatory or circulatory systems to meet elevated oxygen demand, which results in reduced aerobic scope and a transition to anaerobic metabolism under oxygenated conditions. This loss of system function is thought to reflect the earliest level of thermal stress and is known as oxygen and capacity limited thermal tolerance (Pörtner, 2010). Our measurements suggest that thermal stress begins earlier than this critical or "pejus" (Latin for 'turning worse') temperature but protective mechanisms are effective, at least for finite periods of time. Although we did not test heart or ventilatory function directly, the onset of anaerobic metabolism in aerobic conditions is consistent with this mismatch in oxygen supply and an inability to deliver enough oxygen to the body (Pörtner, 2010). Survival beyond the critical temperature leads to a decline in performance and is time limited due to low ATP yield from anaerobic glycolysis (Pörtner, 2002; Pörtner, 2010). 
The pejus range is the range when individuals are past optimum conditions but can still survive with reduced aerobic activity (Jost et al., 2012). During the pejus range, there is an increase in ventilation rate with temperature to compensate for increasing oxygen demand with temperature. At the upper pejus temperature ventilation rate reaches a maximum level and haemolymph $\mathrm{Po}_{2}$ begins to decrease (Frederich and Pörtner, 2000). Oxygen supply to tissues and overall aerobic scope, is obviously linked to fitness and functioning at the ecosystem level (Clark et al., 2013; Pörtner, 2010).

Lactate accumulation at $29^{\circ} \mathrm{C}$ in this study $\left(20.5 \pm 4.52 \mu \mathrm{mol} \mathrm{g}^{-1}\right.$, Figure 4$)$ is similar to the lactate level of $17.15 \pm 4.75 \mu \mathrm{mol} \mathrm{g}^{-1}$ in the same species subjected to five hours of environmental hypoxia ( $1 \%$ oxygen) at the intermediate temperature of $20^{\circ} \mathrm{C}$. Lactate concentrations at $25^{\circ} \mathrm{C}$ and below were comparable to levels in the previous study when exposed to normoxic conditions $2.85 \pm 0.40 \mu \mathrm{mol} \mathrm{g}^{-1}$ (Elder and Seibel, In Revision). This indicates that individuals were experiencing tissue level hypoxia at $29^{\circ} \mathrm{C}$ despite access to high seawater oxygen levels. This tissue level hypoxia could be due in part to failure of ventilatory or circulatory systems. However, factors other than oxygen transport can also be thermally limited and potentially cause decline in performance and temperature tolerance. These factors could include cell damage, membrane fluidity, enzyme function, and neural function (Clark et al., 2013).

A critical temperature of approximately $30^{\circ} \mathrm{C}$ is found in several other crustacean species. The spider crab Maja squinado from Roscoff France has a critical temperature close to $30^{\circ} \mathrm{C}$, which was indicated by accumulation of anaerobic end products succinate and lactate. This coincided with very low arterial $\mathrm{Po}_{2}$ values (Frederich and Pörtner, 2000). The critical temperature range at which anaerobic metabolism begins in the intertidal crabs Carcinus maenas and Cancer irroratus is $34^{\circ} \mathrm{C}$ and $30^{\circ} \mathrm{C}$, respectively. Interestingly, hsp 70 was not detected in either of these 
crabs, but it may be due to the experimental design, which included a rapid rate of temperature increase (Jost et al., 2012). Our results suggest at least an 8 hour lag (3 h initial exposure and 5 hour subsequent exposure) in the onset of hsp70 expression following exposure to stressful temperatures.

The majority of studies on heat shock response in ectothermic invertebrates have focused on intertidal organisms, especially mussels. A theme from these studies is the plasticity of hsp expression, where past thermal history has an impact on induction temperature (Hofmann, 2005; Hofmann et al., 2002). In the intertidal, thermal history can vary with season and tide level. In temperate regions of the pelagic realm, seasonal changes can have an effect on surface temperatures. In the tropics however, temperature gradients are steep but relatively stable (Fernández-Álamo and Färber-Lorda, 2006). Vertical migators experience drastic temperature changes during their transit between surface and deeper waters. The lack of a full stress response in Phronima sedentaria at $23^{\circ} \mathrm{C}$ indicates that this species is adapted to the current, relatively constant, surface temperatures of the region.

Vertically migrating calanoid copepods (Calanus finmarchicus) from the temperate waters of the Gulf of Maine demonstrated a heat shock response when exposed to their maximum summer habitat temperature $\left(20^{\circ} \mathrm{C}\right)$ (Voznesensky et al., 2004). After 30 minutes at $20^{\circ} \mathrm{C}$ individuals exhibited a $\sim 4$ fold increase in hsp 70 expression (Voznesensky et al., 2004). The heat shock response in these vertically migrating copepods may increase survival by allowing them to tolerate high temperatures while at the surface before migrating down to deep, cooler waters (Voznesensky et al., 2004). The individuals of $P$. sedentaria examined here were acclimated to their winter temperatures. Summer temperatures may reach $30^{\circ} \mathrm{C}$ (Pennington et al., 2006). 
High constitutive levels of hsp 70 are thought to provide a general protective mechanism against heat shock, and possibly other stresses, in freshwater amphipods (Bedulina et al., 2013). There was a stronger hsp response in intertidal amphipods from a variable habitat (sub-littoral) versus a less variable habitat (supra-littoral) (Bedulina et al., 2010). This may indicate that the heat-shock response is critical for tolerating natural temperature fluctuations, even below critical extremes. Rhythmic pre-synthesis of hsps to prepare for potential heat stress, such as prior to low tide, has not been found in rocky intertidal organisms (Hofmann et al., 2002). The dependable timing of diel migration compared to the variability of low tide levels, suggest that vertical migrators would be more likely to have an anticipatory increase in hsp production than intertidal organisms. For this study 24 hour I-exposure specimens were frozen at 0100, 9 hour I-exposure specimens were frozen at 1300 and 3 hour I-exposure specimens were frozen at 0700 . At 0100 diel migrators would have been at the surface for a few hours, while at 0700 they would have recently arrived at depth and at 1300 they would have arrived at depth several hours prior. If $P$. sedentaria were producing hsp in anticipation of vertical migration, one would expect lower levels of hsp in the group subjected to the same temperature frozen at 1300 compared to the group frozen at 0100 . However, there was no significant difference in the hsp concentrations or level of mortality between the freezing times.

\section{Conclusions}

Upper thermal tolerance limits are correlated with the maximum habitat temperatures in intertidal organisms (Stillman and Somero, 2000). In the midwater environment Phronima sedentaria's critical temperature of $29^{\circ} \mathrm{C}$ may be reached in summer and, due to global warming (Deser et al., 2010), during future winters. The Eastern Tropical Pacific warms by approximately 
$0.8-1.0^{\circ} \mathrm{C}$ per century (Deser et al., 2010). If organisms are already close to their critical temperatures, global warming may cause some species to exceed their thermal limits and may affect their biogeographic range. Increasing temperature and decreasing oxygen supply (Keeling et al., 2010; Stramma et al., 2008) will compress the night time habitat of vertically migrating species (Elder and Seibel, In Revision; Seibel, 2011). This change will have important impacts on zooplankton physiology, ecology, and vertical distribution as well as carbon cycling (Vinogradov and Voronina 1962; Seibel 2011; Somero 2002).

Acknowledgments. Thanks to Gretchen Hofmann for numerous insightful discussions. The Hofmann Lab provided the thermal gradient block design which was fabricated by the Equipment Development Lab at the URI Graduate School of Oceanography. This work would not have been possible without the Captain and Crew of the R/V Knorr. Thank you to the members of the Seibel lab for assistance in net deployment and recovery, and to Kendra Daly for her organization of the ETP research expedition. A special thanks to Niall Howlett, and the members of the Howlett lab (especially Rebecca Boisvert and Meghan Rego), for use of equipment, assistance with western blot methods and troubleshooting. Thanks to Terry Bradley, Karen Wishner and three anonymous reviewers for helpful comments and suggestions on earlier versions of the manuscript that improved our work. Funded was provided by the National Science Foundation grants: OCE-0526545 to Kendra Daly and OCE-0526502 to Karen Wishner and Brad Seibel. Additional funding was provided by The Crustacean Society Graduate Student Fellowship to Leanne Elder and the University of Rhode Island Enhancement of Graduate Research grant, also to Leanne Elder. 


\section{References}

Bedulina, D., Evgen'ev, M., Timofeyev, M., Protopopova, M., Garbuz, D., Pavlichenko, V., Luckenbach, T., Shatilina, Z., Axenov-Gribanov, D., Gurkov, A., Sokolova, I.M., Zatsepina, O.G., 2013. Expression patterns and organization of the hsp70 genes correlate with thermotolerance in two congener endemic amphipod species (Eulimnogammarus cyaneus and E. verrucosus) from Lake Baikal. Molecular Ecology 22, 1416-1430.

Bedulina, D., Zimmer, M., Timofeyev, M., 2010. Sub-littoral and supra-littoral amphipods respond differently to acute thermal stress. Comparative Biochemistry and Physiology Part B 155, 413418.

Childress, J.J., 1975. The respiratory rates of midwater crustaceans as a function of depth of occurrence and relation to the oxygen minimum layer off southern California. Comparative Biochemistry and Physiology Part A 50, 787-799.

Childress, J.J., Barnes, A.T., Quetin, L.B., Robison, B., 1978. Thermally protecting cod ends for the recovery of living deep-sea animals. Deep-Sea Research 25, 419-422.

Clark, L.C., 1956. Monitor and control of blood and tissue oxygen tensions. Transactions - American Society for Artificial Internal Organs 2, 41-48.

Clark, T.D., Sandblom, E., Jutfelt, F., 2013. Aerobic scope measurements of fishes in an era of climate change: respirometry, relevance and recommendations. The Journal of Experimental Biology 216, 2771-2782.

Deser, C., Phillips, A.S., Alexander, M.A., 2010. Twentieth century tropical sea surface temperature trends revisited. Geophysical Research Letters 37, 1-6.

Diebel, C.E., 1988. Observations on the anatomy and behavior of Phronima sedentaria (forskal) (amphipod: hyperiidea). Journal of Crustacean Biology 8, 79-90.

Doney, S.C., Ruckelshaus, M., Duffy, J.E., Barry, J.P., Chan, F., English, C.A., Galindo, H.M., Grebmeier, J.M., Hollowed, A.B., Knowlton, N., Polovina, J., Rabalais, N.N., Sydeman, W.J., Talley, L.D., 2012. Climate change impacts on marine ecosystems. Annual Review of Marine Science 4, 11-37.

DuBeau, S.F., Pan, F., Tremblay, G.C., Bradley, T.M., 1998. Thermal shock of salmon in vivo induces the heat shock protein hsp 70 and confers protection against osmotic shock. Aquaculture 168, 311323.

Elder, L.E., Seibel, B.A., In Revision. Ecophysiological implications of vertical migration into oxygen minimum zones for the hyperiid amphipod Phronima sedentaria. Journal of Plankton Research.

Feder, M.E., Hofmann, G.E., 1999. Heat-shock proteins, molecular chaperones, and the stress response: Evolutionary and Ecological Physiology. Annual Reviews in Physiology 61, 243-282.

Fernández-Álamo, M.A., Färber-Lorda, J., 2006. Zooplankton and the oceanography of the eastern tropical Pacific: A review. Progress in Oceanography 69, 318-359.

Frederich, M., Pörtner, H.O., 2000. Oxygen limitation of thermal tolerance defined by cardiac and ventilatory performance in spider crab, Maja squinado. American Journal of Physiology Regulatory, Integrative and Comparative Physiology 279, R1531-R1538.

Gasca, R., Haddock, S.H.D., 2004. Associations between gelatinous zooplankton and hyperiid amphipods (Crustacea: Peracarida) in the Gulf of California. Hydrobiologia 530, 529-535.

Harbison, G., Biggs, D., Madin, L., 1977. The associations of Amphipoda Hyperiidea with gelatinous zooplankton-II. Associations with Cnidaria, Ctenophora and Radiolaria. Deep Sea Research 24, 465-488.

Henkel, S.K., Hofmann, G.E., 2008. Thermal ecophysiology of gametophytes cultured from invasive Undaria pinnatifida (Harvey) Suringar in coastal California harbors. Journal of Experimental Marine Biology and Ecology 367, 164-173. 
Hirose, E., Aoki, M.N., Nishikawa, J., 2005. Still alive? Fine structure of the barrels made by Phronima (Crustacea: Amphipoda). Journal of the Marine Biological Association of the United Kingdom 85, 1435-1439.

Hofmann, G.E., 2005. Patterns of Hsp gene expression in ectothermic marine organisms on small to large biogeographic scales. Integrative and Comparative Biology 45, 247-255.

Hofmann, G.E., Buckley, B.A., Place, S.P., Zippay, M.L., 2002. Molecular chaperones in ectothermic marine animals: biochemical function and gene expression. Integrative and Comparative Biology, 808-814.

Hofmann, G.E., Somero, G.N., 1995. Evidence for protein damage at environmental temperature: seasonal changes in levels of ubiquitin conjugates and hsp70 in the intertidal mussel Mytilus Trossulus. The Journal of Experimental Biology 198, 1509-1518.

Jost, J.A., Podolski, S.M., Frederich, M., 2012. Enhancing thermal tolerance by eliminating the pejus range: a comparative study with three decapod crustaceans. Marine Ecology Progress Series 444, 263-274.

Keeling, R.F., Körtzinger, A., Gruber, N., 2010. Ocean deoxygenation in a warming world. Annual Review of Marine Science 2, 199-229.

Land, M.F., 1992. Locomotion and visual behaviour of mid-water crustaceans. Journal of the Marine Biological Association of the United Kingdom 72, 41-60.

Laval, P., 1978. The barrel of the pelagic amphipod Phronima sedentaria (Forsk.) (crustaces: Hyperiidea). Journal of Experimental Marine Biology and Ecology 33, 187-211.

Madin, L.P., Harbison, G.R., 1977. The associations of Amphipoda Hyperiidea with gelatinous zooplankton--I. Associations with Salpidae. Deep Sea Research 24, 449-463.

Pennington, J.T., Mahoney, K.L., Kuwahara, V.S., Kolber, D.D., Calienes, R., Chavez, F.P., 2006. Primary production in the eastern tropical Pacific: A review. Progress in Oceanography 69, 285-317.

Pörtner, H.O., 2002. Climate variations and the physiological basis of temperature dependent biogeography: systemic to molecular hierarchy of thermal tolerance in animals. Comparative Biochemistry and Physiology Part A 132, 739-761.

Pörtner, H.O., 2010. Oxygen-and capacity-limitation of thermal tolerance: a matrix for integrating climate-related stressor effects in marine ecosystems. The Journal of Experimental Biology 213, 881-893.

Saltzman, J., Wishner, K.F., 1997. Zooplankton ecology in the eastern tropical Pacific oxygen minimum zone above a seamount: 1. General trends. Deep Sea Research Part I 44, 907-930.

Schulte, P.M., 2014. What is environmental stress? Insights from fish living in a variable environment. The Journal of experimental biology 217, 23-34.

Seibel, B.A., 2011. Critical oxygen levels and metabolic suppression in oceanic oxygen minimum zones. The Journal of Experimental Biology 214, 326-336.

Shih, C.-t., 1969. The systematics and biology of the family Phronimidae (Crustacea: Amphipoda). Dana Reports no. 74, 1-100.

Shih, C.-t., 1991. Description of two new species of Phronima Latreille, 1802 (Amphipoda: Hyperiidea) with a key to all species of the genus. Journal of Crustacean Biology 11, 322-335.

Shulenberger, E., 1977. Hyperiid amphipods from the zooplankton community of the North Pacific central gyre. Marine Biology 42, 375-385.

Sokolova, I.M., Portner, H.O., 2003. Metabolic plasticity and critical temperatures for aerobic scope in a eurythermal marine invertebrate (Littorina saxatilis, Gastropoda: Littorinidae) from different latitudes. Journal of experimental biology 206, 195-207.

Somero, G.N., 1995. Proteins and temperature. Annual review of physiology 57, 43-68.

Somero, G.N., 2002. Thermal physiology and vertical zonation of intertidal animals: optima, limits, and costs of living. Integrative and Comparative Biology 42, 780-789. 
Somero, G.N., 2010. The physiology of climate change: how potentials for acclimatization and genetic adaptation will determine 'winners' and 'losers'. Journal of Experimental Biology 213, 912-920.

Sørensen, J.G., Kristensen, T.N., Loeschcke, V., 2003. The evolutionary and ecological role of heat shock proteins. Ecology Letters 6, 1025-1037.

Stillman, J.H., Somero, G.N., 2000. A comparative analysis of the upper thermal tolerance limits of eastern Pacific porcelain crabs, genus Petrolisthes: influences of latitude, vertical zonation, acclimation, and phylogeny. Physiological and Biochemical Zoology 73, 200-208.

Stramma, L., Johnson, G.C., Sprintall, J., Mohrholz, V., 2008. Expanding oxygen-minimum zones in the tropical oceans. Science 320, 655.

Trenberth, K.E., Jones, P.D., Ambenje, P., Bojariu, R., Easterling, D., Klein Tank, A., Parker, D., Rahimzadeh, F., Renwick, J.A., Rusticucci, M., 2007. Observations: Surface and Atmospheric Climate Change. Climate Change 2007: The Physical Science Basis. Contribution of Working Group I to the Fourth Assessment Report of the Intergovernmental Panel on Climate Change. S. Solomon, D. Qin, M. Manning, et al. Cambridge, United Kingdom and New York, NY, USA., Cambridge University Press.

Vinogradov, M.E., Volkov, A.F., Semenova, T.N., Siegel-Causey, D., 1996. Hyperiid amphipods (Amphipoda, Hyperiidea) of the world oceans. Science Publications Incorporated, Lebanon, USA. Voznesensky, M., Lenz, P.H., Spanings-Pierrot, C., Towle, D.W., 2004. Genomic approaches to detecting thermal stress in Calanus finmarchicus (Copepoda: Calanoida). Journal of Experimental Marine Biology and Ecology 311, 37-46.

\section{Legends}

Figure 1. Eastern Tropical North Pacific sites. This map displays the station in the Eastern Tropical North Pacific (ETNP) during collection aboard the R/V Knorr in Dec 2008- Jan 2009. Individuals for these experiments were collected at the Costa Rica Dome $\left(8.5^{\circ} \mathrm{N}, 90^{\circ} \mathrm{W}\right)$ using a tucker trawl.

Figure 2. CTD profile for the Costa Rica Dome. The Costa Rica Dome CTD profile of oxygen (black line) and temperature (grey line). Boxes represent approximate day and night time distributions of Phronima sedentaria based on published distributions (Shih, 1991; Shulenberger, 1977).

Figure 3. Thermal gradient block. The thermal block consisted of a piece of aluminum with holes drilled through each end fitted with brass inlet and outlet ports to accommodate heating 
and chilling lines. The heating lines are to the left side of the block and separate chilling lines are on the right side. Water flows from the water bath through the tubing and the block and back to the water bath. By having the two water baths at opposing extreme temperatures there is a temperature gradient in the wells on the top.

Figure 4. Phronima sedentaria lactate accumulation from thermal stress experiments. Average accumulation of lactate in $\mu \mathrm{mol} \mathrm{g}^{-1}$ for Phronima sedentaria at each subsequent exposure (S-exposure) temperature. All values are mean \pm se. There was a significantly higher accumulation of lactate at $29^{\circ} \mathrm{C}$.

Figure 5. Western blot analysis of hsp 70 levels in Phronima sedentaria. Representative Western blot analysis of levels of hsp 70 in Phronima sedentaria relative to control (HELA cells first lane on the left). The marker from the protein ladder at $75 \mathrm{Kda}$ is indicated in the figure, to show that the band is at $70 \mathrm{Kda}$. This gel consists of the samples with a 24 hours Initial exposure to $23^{\circ} \mathrm{C}$ and subsequent exposure to the designated temperatures. The last three lanes (samples that have been kept at $29^{\circ} \mathrm{C}$ ) had significantly higher relative intensity than the other samples, indicating significantly higher hsp 70 concentration.

\section{Figure 6. Phronima sedentaria mean hsp70 concentrations following thermal stress}

experiments. Mean hsp 70 concentration \pm se for individuals initially exposed to night time temperature of $23^{\circ} \mathrm{C}$ for 3 (gray), 9 (black) or 24 hours (white) followed by subsequent exposure (S-exposure) to the designated temperatures. * indicates there was a significantly lower hsp 70 concentration at 3 hours compared to 9 and 24 hours ( $\mathrm{p}$ value $<0.05$ ). ** indicates there was a 
nearly significant increase in hsp 70 concentration in individuals acclimated to $23 \mathrm{C}$ for 24 hours before a five hour incubation at $29^{\circ} \mathrm{C}$ 
Figure 1

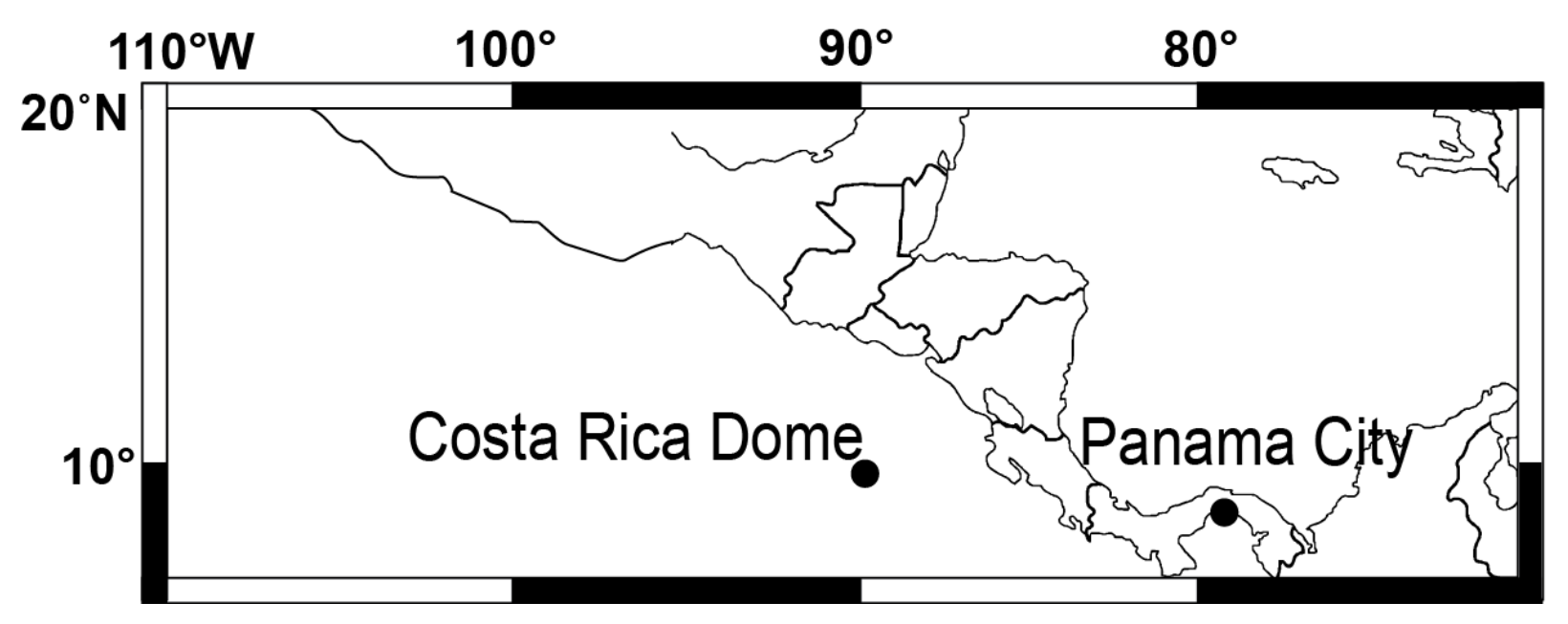


Figure 2

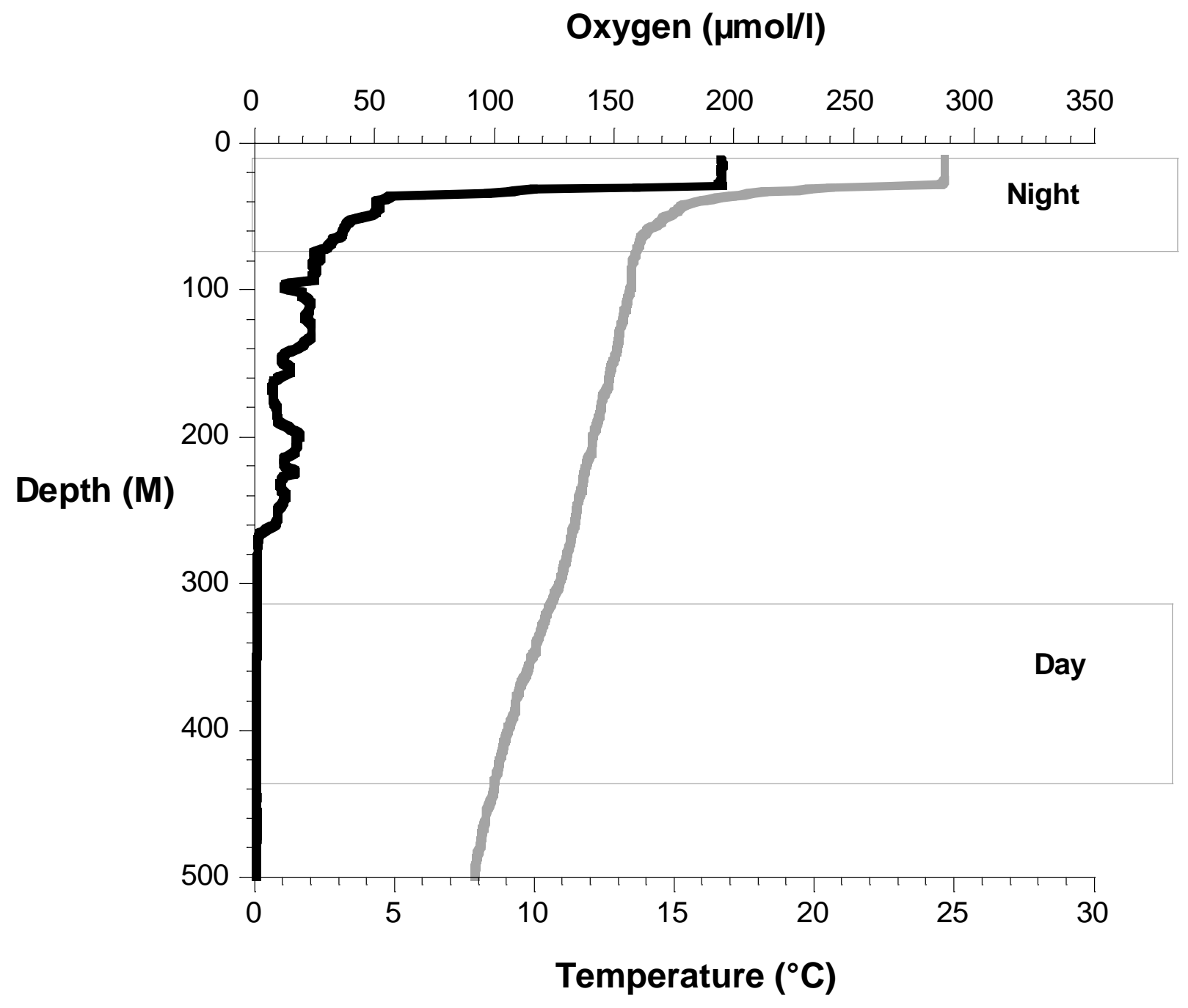


Figure 3

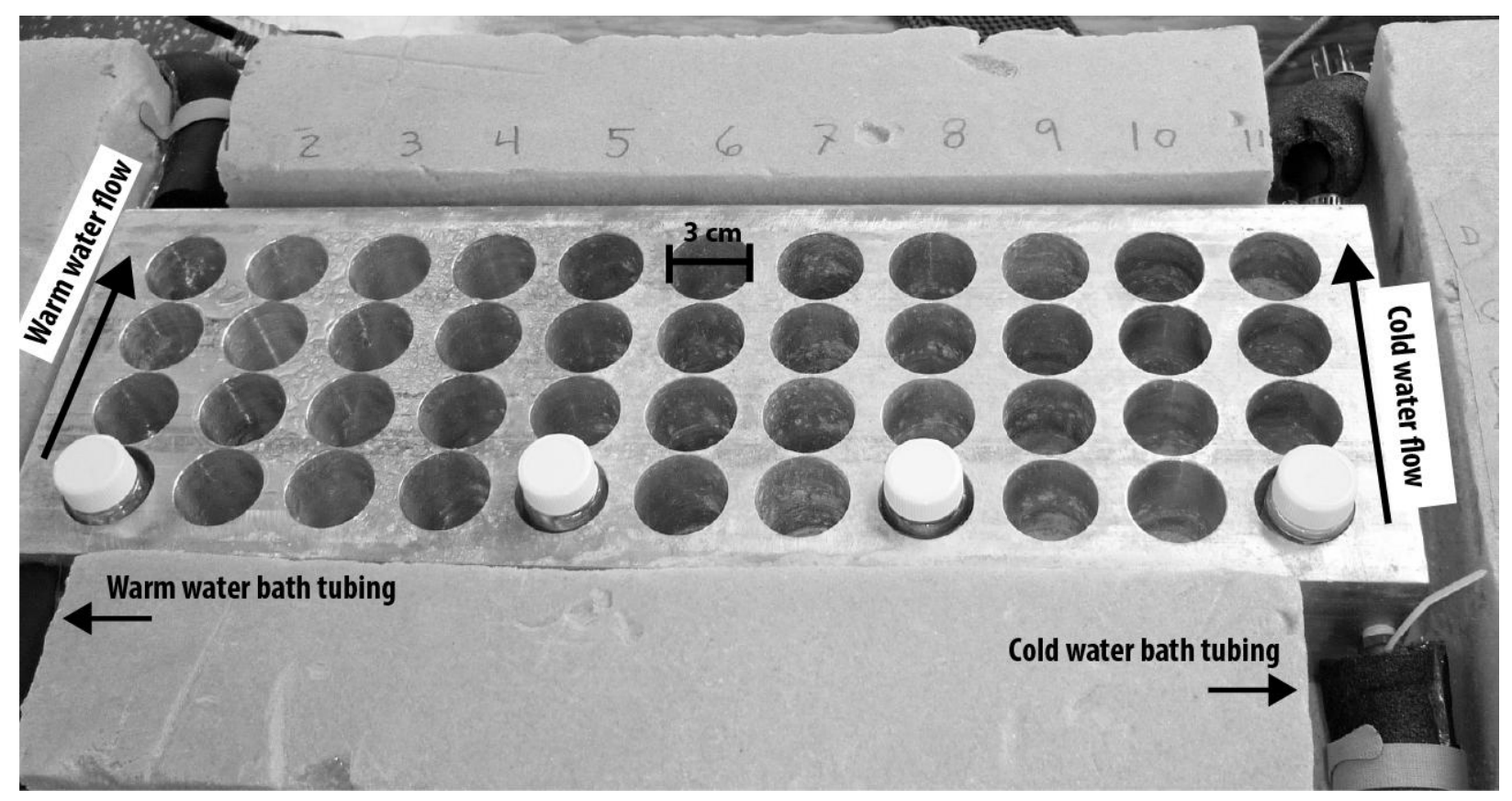


Figure 4

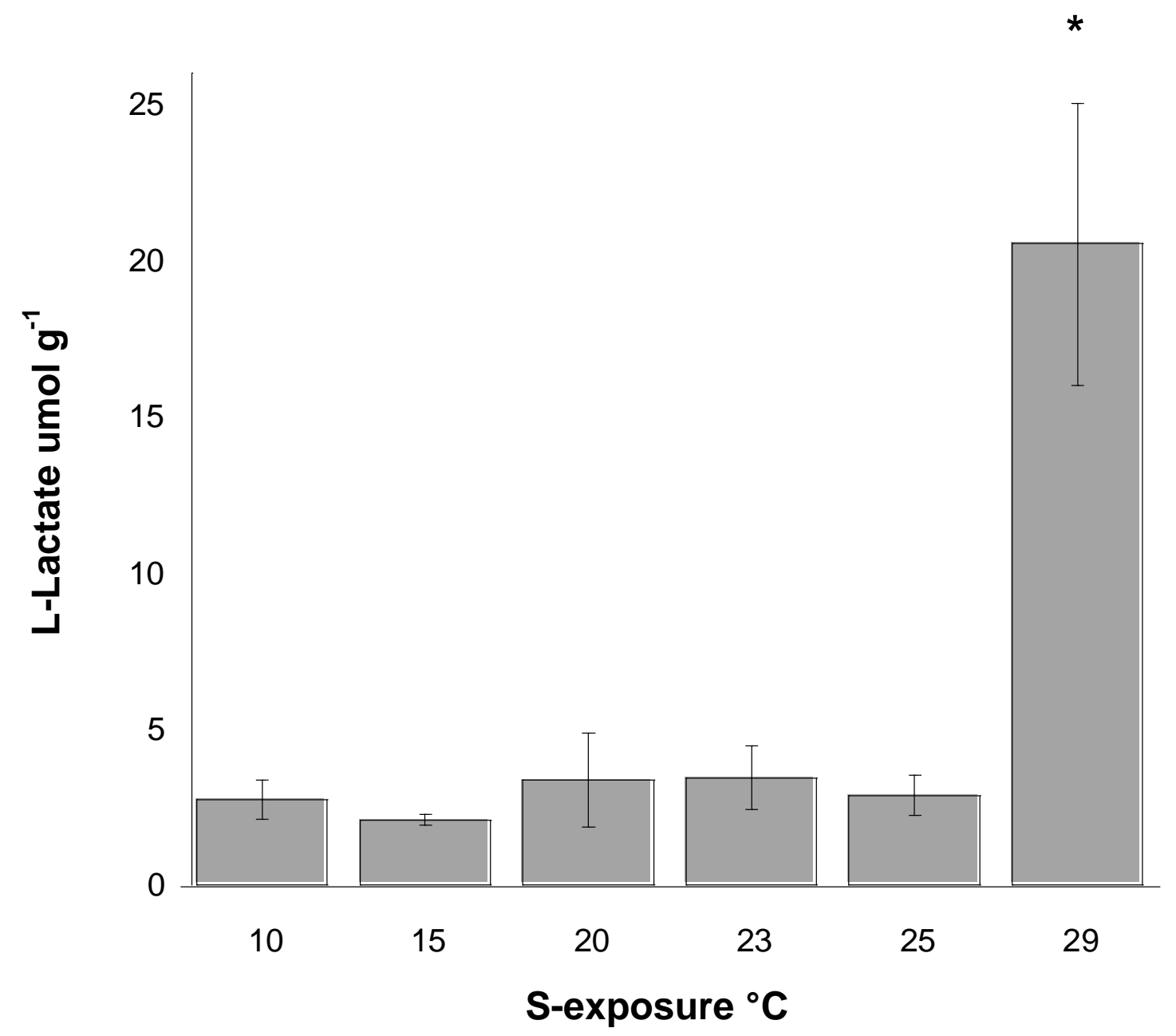


Figure 5

$75 \mathrm{Kda}$

$10^{\circ} \mathrm{C} \quad 15^{\circ} \mathrm{C} \quad 20^{\circ} \mathrm{C} \quad 24^{\circ} \mathrm{C} \quad 29^{\circ} \mathrm{C}$ 
Figure 6

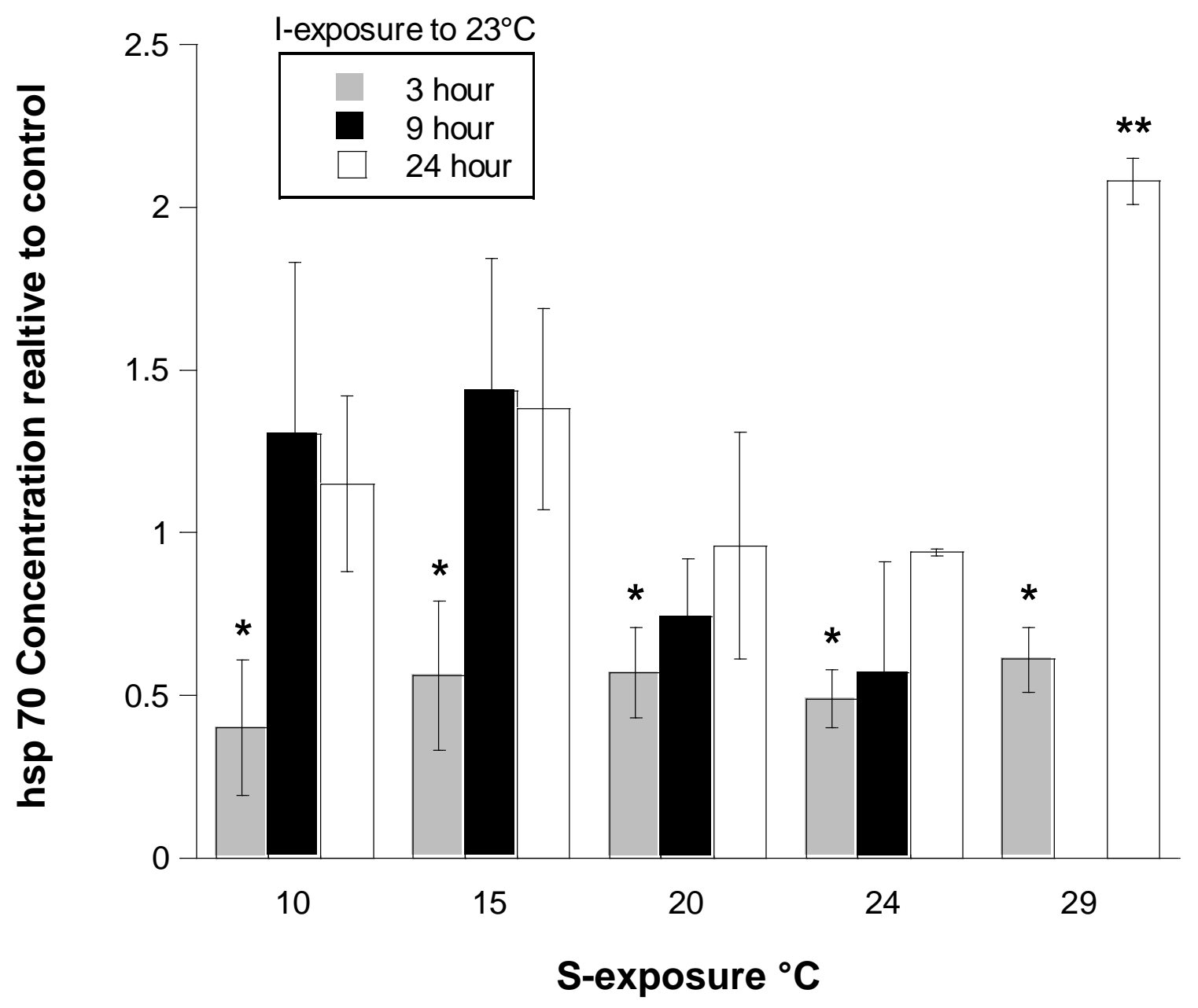


Table 1. Experimental design for thermal stress experiments on Phronima sedentaria.

\begin{tabular}{|c|c|c|c|}
\hline \multirow{3}{*}{ I-exposure to $\mathbf{2 3}^{\circ} \mathbf{C}$} & $\begin{array}{c}\text { S-exposure } \\
\text { temperature } \\
{ }^{\circ} \mathbf{C}\end{array}$ & $\mathbf{n}$ & $\begin{array}{c}\text { n dead at } \\
\text { end }\end{array}$ \\
\hline \multirow{4}{*}{3 hours } & 10 & 4 & \\
\cline { 2 - 4 } & 15 & 4 & \\
\cline { 2 - 4 } & 20 & 4 & \\
\cline { 2 - 4 } & 23 & 4 & \\
\hline \multirow{5}{*}{9 hour } & 29 & 4 & 3 \\
\hline & 10 & 4 & \\
\cline { 2 - 4 } & 15 & 4 & \\
\hline & 20 & 4 & \\
\hline \multirow{5}{*}{24 hour } & 23 & 3 & 1 \\
\hline & 25 & 3 & 2 \\
\hline & 10 & 3 & \\
\hline & 15 & 3 & \\
\hline & 20 & 3 & \\
\hline & 25 & 3 & \\
\hline & 29 & 3 & \\
\hline
\end{tabular}

Thermal stress experimental setup for initial exposure (I-exposure) to night time temperature of $23^{\circ} \mathrm{C}$ for 3,9 or 24 hours and subsequent exposure (S-exposure) for five hours to the designated S-exposure temperature. $\mathrm{n}$ is number of individuals kept at those conditions. $\mathrm{n}$ deceased at end is the number deceased at the end of each experiment. 